Article

\title{
Living Suspiciously: Contingent Belonging in British South Asian Theater
}

\author{
Ariane de Waal \\ Department of English and North American Studies, MLU Halle-Wittenberg, 06108 Halle (Saale), Germany; \\ ariane.de-waal@anglistik.uni-halle.de
}

Received: 3 July 2020; Accepted: 3 August 2020; Published: 18 August 2020

check for updates

\begin{abstract}
This article investigates representations of national belonging in British South Asian theater productions after the 2005 London bombings. It identifies a significant yet hitherto underresearched corpus of plays that show the formation of the UK "home front" in the war on terror from the perspective of postcolonial subjects who are deemed threatening rather than worthy of protection. After discussing the construction of British South Asian citizens as suspicious subjects, the article analyzes two plays that offer an extensive consideration of the contingencies of national belonging. It argues that True Brits by Vinay Patel and Harlesden High Street by Abhishek Majumdar dramatize strategies for building, making, or keeping a home in London in spite of the strictures of suspectification and securitization.
\end{abstract}

Keywords: British South Asian theater; 9/11; 7/7; terrorism; citizenship; racial profiling

\section{Introduction: Citizenship, Contingencies, and British South Asian Theater Since 9/11}

When "ISIS bride" Shamima Begum encountered The Times journalist Anthony Loyd at a Syrian refugee camp in early 2019, she introduced herself in no uncertain terms: "I am a sister from London. I'm a Bethnal Green girl" (quoted in Knight 2020). Even in the face of Begum's unequivocal claim to her British origins, then Home Secretary Sajid Javid reacted to the unexpected discovery of the missing East London schoolgirl by removing her British citizenship. Despite the illegality of making a person stateless, the Home Office has since stood by the decision to bar Begum from returning to the UK, although she was born and raised in the country that she had left in 2015, when she was fifteen years old, to join ISIS in Syria. ${ }^{1}$

The removal of Begum's citizenship is one of the more conspicuous instances shedding light on the precarious status that British citizenship has acquired since the beginning of the US- and UK-led war on terror. Although Javid appealed to the British Nationality Act 1981 to argue that Begum's citizenship could be revoked-citing her parents' links to Bangladesh, a country that Begum protests she has never visited-legislative and public discourse since 9/11 crucially accelerated the process that turned British citizenship from a fundamental right into a provisional privilege. Since the northern English riots and the terror attacks on US soil in $2001,{ }^{2}$ the UK government has made British citizenship not only harder to attain (e.g., by introducing mandatory language courses and the "Life in the UK" test);

1 Legal and political debates surrounding Shamima Begum's case are ongoing at the time of writing. After the first draft of this article was completed, the Court of Appeal ruled that Begum needs to be allowed to return to the UK to fight the Home Office's decision.

2 Sparked by anger over racism, lacking police protection, poverty, and high unemployment rates, the riots occurring in several northern English towns in 2001 "were officially ascribed to [ ... ] Muslim culture" (Samad 2016, p. 74). Subsequent policy initiatives focused primarily on the concept of community cohesion with a view to "reintegrating" ostensibly self-segregating Muslim migrants. 
it has also extended its powers to revoke citizenship with the Immigration, Asylum and Nationality Act 2006 (Kundnani 2007). As a result, those desiring to become or remain British citizens are no longer "entitled" to citizenship but are rather obliged to "earn" it (van Houdt et al. 2011). Beyond the extreme cases of (suspected) terrorists banished from the nation, the reframing of UK citizenship as a tenuous status has had wide-ranging impacts on the lives of minority ethnic Britons, especially those of South Asian and Muslim backgrounds. The domestic discourse of the war on terror, with its attendant emphases on securitization, surveillance, suspicion, and community policing, has scripted British Asian citizenship according to a "sort of racialised postcoloniality", as Joseph Pugliese maintains (Pugliese 2006). According to Pugliese, "the limits of British national belonging for Asian subjects" have become marked by "essentialist constructions of national-identity predicated on proscriptive notions of whiteness" (Pugliese 2006).

This proscriptive whiteness has informed multiple public performances of national belonging and homogeneity, especially since the attacks on the London transport system on 7 July 2005 ("7/7"). The fact that the so-called London bombings were perpetrated by British citizens rather than foreign radicals prompted a redrawing of the domestic boundaries between "us" (white, Christian, peaceful) and "them" (nonwhite, Muslim, deviant). When gathering to watch the hearses carrying fallen British soldiers at Wootton Bassett or publicly resisting the 7/7 bombers' perceived onslaught on "our" values and way of life, "originary" white British citizens were invited to rally around common expressions of grief and to join a national chorus of resilience. In contrast, British Asians, and particularly Muslims, were placed under additional pressure to assimilate, to prove their loyalty to the nation, and to police their own neighbors. Reviving the creation of a "suspect community" from the Troubles in Northern Ireland (Hickman et al. 2011), public discourse, policies, and state measures have systematically destabilized British Asian citizens' sense of being inconspicuously "at home" in the UK. In consequence, citizens with a particular location within intersecting social vectors of (precarious British) national identity, (South Asian) ethnicity, and religion (Muslim or thought to be Muslim) have become suspicious subjects. This article investigates figurations of these newly suspicious subjects in British South Asian theater productions after 7/7, attending particularly to characters' sense of belonging to the national community. In connection with the theme of this special issue, the "disturbances of the home/land" that I focus on are primarily located on a national scale, yet they simultaneously reach into and rely on the actions of patriotic citizens on a neighborhood scale. This mutual constitution of the local and the national manifestations of home is encapsulated in the wartime concept of the "nation-home", which "invests the tangible and affective qualities of home in the otherwise abstract concept of the nation" (Summerfield and Peniston-Bird 2007, p. 10). This concept bears special relevance for drama analysis, where the individual home is typically seen as representative of larger social collectives. In the remainder of this introduction, I will sketch the research terrain in which this article is situated and provide a tentative typology of newly suspicious characters in British South Asian theater after 7/7. The two main sections of the article are devoted to a detailed analysis of the following plays: Vinay Patel's monologue True Brits and Abhishek Majumdar's three-hander Harlesden High Street, performed in London in 2014 and 2013, respectively. Within the corpus of British South Asian productions since $2005,{ }^{3}$ these two plays have been selected for an in-depth discussion because they offer the most extensive consideration of the contingencies surrounding national belonging.

Although Shamima Begum's specific story has yet to be adapted for the stage, British theaters have dramatized the altered status of British Muslims, and South Asians more generally, in post-9/11 society in a wide variety of ways. In the dense field of research that examines text-based UK

3 Besides the plays discussed in this article, this corpus encompasses a wide range of productions, from romantic comedies that offer a defiantly optimistic outlook on multicultural conviviality, such as Alia Bano's Shades (2009) or Karla Crome's Mush and Me (2014), to plays addressing the more serious themes of racial profiling and police violence (e.g., Raman Mundair's The Algebra of Freedom, 2007) or the interrogation and torture of British Asian detainees at Guantánamo Bay (e.g., Nirjay Mahindru's The Hot Zone, 2005). 
theater in response to the war on terror (Boll 2013; de Waal 2017; Finburgh 2017; Hughes 2011; Soncini 2015), scholars rarely foreground the work of South Asian playwrights or theater companies. Conversely, although critical attention to British South Asian theater has grown substantially since the initiatives of the British Asian Theatre research project (2004-2009) at the University of Exeter (Daboo 2018; Hingorani 2010; Ley and Dadswell 2012a, 2012b), the expanding scholarship that centers on Asian-led companies seldom focuses on (counter)terrorist themes. Even though various scholars and artists have problematized the nomenclature surrounding "this Thing Called British Asian Theatre" (Dadswell 2009), rightly pointing out that Asian theater should not be located outside of the UK mainstream, I would submit that the sheer amount of work by playwrights and practitioners of South Asian descent addressing the situation of British Asians after 7/7 warrants a specific discussion of this corpus. I take up the terminology "British South Asian theater" from scholars such as Graham Ley and Sarah Dadswell in the hope of supporting attempts to redress substantial gaps in theater scholarship (including my own work), for "British South Asian theatre has been inadequately documented" and, to this day, "has not received the critical attention it requires" (Ley and Dadswell 2012b, p. 1). Taking into account the pitfalls of establishing some kind of ethnically marked subcategory of British theater, I do not propose to distill a particular South Asian aesthetic or mode of representation. Instead, this article aims to examine how British Asian productions have raised specific concerns about national belonging in the war on terror era. Since my interest lies in the ways in which these plays take up, reflect on, and respond to wider political discourses and sociocultural developments, I draw on various scholarly sources beyond the field of theater and performance studies. My analysis is particularly indebted to the work of cultural theorist Sara Ahmed (The Cultural Politics of Emotion, 2004) and sociologist Les Back (The Art of Listening, 2007), both of whom have insightfully attended to the sonic and affective shifts caused by counterterrorist agendas.

In the aftermath of the London bombings and the introduction of enhanced race-based security measures in the UK, British South Asian theater has offered a sustained focus on the culture of suspicion and its derogatory impact. Plays staged in theaters in London and across the nation have routinely featured characters wrongly suspected to be terrorists due to racial profiling. A key scene in this respect involves what I have elsewhere called the "travelling terrorist figure", i.e., "the racialized male carrying a rucksack on public transport [that] has become an iconic figure of the new landscape of urban fear" (de Waal 2017, pp. 85-86). We meet this figure in Atiha Sen Gupta's play What Fatima Did ... , which premiered at Hampstead Theatre in London in 2009 as one of the first mainstage productions to engage with the domestic experiences of British Muslims after 7/7. In Sen Gupta's play, the teenager Mohammed explicitly distinguishes his encounters with Islamophobia from the racism previous generations of British Asians had to endure:

Times have changed! [ ... ] They don't even hate Asians anymore, they hate us ... specifically us [ ... ]. Some days I can barely go out on the street, on the tube, to school [ ... ]. [T]he amount of fucking times I've got on the train and people have moved away from me [... ]. When you see a white person with a backpack on, everyone thinks backpacker. ... But when you see an Asian with a backpack on, you're only left with terrorist. (Sen Gupta 2009, pp. 88-89)

Three features of Mohammed's speech have come to be defining for British South Asian characters in post-7/7 drama. First, he articulates his subjective position directly in relation to the war on terror, signaling a new era of racial profiling and suspicion ("Times have changed!"). Mohammed highlights the additional vector of discrimination that makes the situation of British Asian Muslims doubly untenable, with a toxic mix of racial and religious hatred ("they hate us ... specifically us"). As Tariq Modood argues, this double discrimination has afflicted South Asian communities in the UK more generally since the beginning of the war on terror. "South Asians", he writes, "are a principal object of racist victimization" (Modood 2005, p. 7). They not only suffer from "color racism" but also from "cultural racism" (Modood 2005, p. 7) because their supposed cultural values are considered incompatible with British citizenship and community cohesion. Second, like many other figures in British South Asian theater, Mohammed struggles to disidentify with the indelible terrorist label that sticks to his body 
whenever he enters public spaces. Because of the perception that "an Asian with a backpack on" can only be a "terrorist", he has no means of averting suspicion. Third, as a consequence, Mohammed's mobility in the post-7/7 city is restricted. His claims to belonging to the nation and his ability to move inconspicuously and blend into the population are denied thanks to innumerable public campaigns and service announcements that have trained citizens to be wary of their fellow (read "brown") travelers (Sharma 2006, p. 135). What Fatima Did ... , like many other British South Asian theater productions after $7 / 7$, explores how postcolonial subjects live with and despite this predicament.

This is what differentiates British South Asian theater from the larger corpus of British "plays and productions that question the spectacularization of so-called terrorism" (Finburgh 2017, p. 20). Numerous British playwrights have situated overly anxious, grieving, or paranoid citizens on the domestic "home front" of their dramatized worlds: whether in Mark Ravenhill's play cycle Shoot/Get Treasure/Repeat (2007) or Dennis Kelly's plays Osama the Hero (2005) and After the End (2005), such recurring theatrical figures take homeland defense into their own hands. They capture, brand, and kill supposed terrorists; build nuclear fallout shelters; hide behind the walls of gated communities; or install ever-more-sophisticated surveillance systems. By contrast, the homes, neighborhoods, and public spaces that emerge in British South Asian productions do not afford characters the position of vulnerable victims or patriotic protectors of the nation. Instead, these spaces are increasingly hard to navigate. British South Asian theater shows the formation of the "home front" in the war on terror from the perspective of postcolonial subjects-subjects deemed threatening rather than worthy of protection. By transforming the fear-inducing caricature of the traveling terrorist into a multidimensional subject whose own fears and anxieties are laid bare to the audience, these productions have the potential to powerfully challenge the detrimental impact of counterterrorist discourse and practices.

\section{2. “It May Be a Shithole, But It's My Shithole": Stubborn Belonging in Vinay Patel's True Brits (2014)}

True Brits was the first full-length play penned by London-based dramatist Vinay Patel, who went on to write a number of critically acclaimed theater and television scripts (including two Doctor Who episodes) that address topics such as Partition in India, arranged marriage, and so-called honor killings. The monologue True Brits was first shown at the Edinburgh Festival Fringe in 2014 and transferred to the Bush Theatre in London for a RADAR double bill the same year. The protagonist, Rahul (originally portrayed by Sid Sagar), is a third-generation Gujarati living in South East London. The monologue moves back and forth between two decisive years in London's history that coincide with Rahul's own coming-of-age story. His narrative of falling and failing in love in the months leading up to the bombings in July 2005 is framed and interspersed by parts of the monologue that are set during the London 2012 Olympics. True Brits synchronizes these historic events with a postcolonial coming-of-age trajectory, thereby throwing into sharp relief the impact on the lives of British South Asians produced by the discourse on (the supposed death of) multiculturalism and (the alleged assault on) British values.

The monologue begins evocatively with the question, "Do you feel British?" (Patel 2014, p. 5). A BBC journalist asks Rahul this question as he steps out of the Olympic Park during the 2012 games, but the actor simultaneously, implicitly, raises it to the diverse London audience gathered to see the play-at least this was the case when I attended the performance at the Bush Theatre in 2014. This opening question effectively prefaces the play's engagement with national identity in the war on terror period. The BBC journalist morphs, over the course of the play, into a plethora of unseen white Britons who doubt or challenge Rahul's belonging to the national community in infinite variations. There is the teenager at a playground who provocatively asks "Where you from?" (p. 11) before headbutting Rahul; the father of his girlfriend, who suddenly demands to know over dinner whether or not Rahul is a Muslim (p. 26); the elderly woman on a train who is "staring" at him (p. 30); and there are the various police officers who stop and search him while allegedly "conducting random searches under the Prevention of Terrorism Act" (p. 31). As in What Fatima Did ... , the specific conflict into which Rahul finds himself propelled results directly from the changed political climate after the 
2005 London bombings. Like Mohammed, Rahul distinguishes his own experience of becoming a suspect from the challenges faced by his grandfather, who immigrated to the UK for economic reasons, and his mother, who grew up during the prevalent racist violence of 1970s Britain. Rahul makes it clear that both the first- and second-generation Gujaratis in his family would have a more straightforward answer as to whether or not they felt British. While his grandfather "came here to be British [ ... ], so I could belong here" (p. 5), his mother, who associates the Union Jack with the "bricks that would fly into her bedroom when she was a kid" (p. 6), has come to the conclusion that "we still don't belong" (p. 6). For Rahul, the question of belonging is more complicated than his grandfather's urgent wish to be accepted into the national community and his mother's retreat from efforts to belong. On the one hand, he feels more unquestionably British than the generations before him; on the other hand, his right to feel at home in London and to live and move, unimpeded, in the city are challenged in more insidious ways.

However British he might "feel", Rahul is shut out from the national community of feeling coalescing around the shared affect of anxiety after the London bombings. The attacks on the London transport system take place while Rahul is away on a stereotypically British post-A-levels "Lads on Tour" (p. 22) vacation on the Spanish coast. While his mother immediately anticipates a rise in race-related violence, texting Rahul with the advice to "Shave your beard off" (p. 23), Rahul is still oblivious as to what all "the extra security" (p. 23) at the airport might entail for his personal sense of safety, or lack thereof, as he gets off the plane. Assessing the situation like the impressionable teenager he still is, he observes, "I've never seen a machine gun in real life, only on PlayStation. They look heavy. But it's good to be home" (p. 23). When Rahul takes the bus to see his girlfriend for the first time after the bombings, however, he begins to notice the way his body has started to draw attention on public transport. Traveling through the neighborhood that he will soon leave behind to start university, Rahul is hit "with an unexpected wave of nostalgia. It may be a shithole, but it's my shithole and I know I'm gonna miss all this" (p. 25). At the precise moment when Rahul could not feel more ownership over his local origins, a young boy approaches him to shake him out of his complacency:

'Who are those for?'

'My girlfriend.' It's still fun to say that.

'Does she like flowers?'

[ ... ] 'Course. Everyone likes flowers, so I'm giving her flowers.'

'Why? Did you try to blow her up?' (p. 25)

Although received as a "dark joke" (p. 25), the boy's insolent question imparts to Rahul the new scripts of UK public life: Rahul can no longer claim to be an ordinary passenger, a teenager taking flowers to his girlfriend's house; he will invariably be racially profiled as a terrorist suspect. The scripts of naïve heterosexual teenage romance-it is fun to call someone your "girlfriend", and "Everyone likes flowers"-no longer provide credible lines to profess innocuous British citizenship. Whereas, in his own perception, Rahul counts as a "real" local insofar as he can experience attachment to a place where others would only detect "a stench of piss" (p. 25), his brief moment of nostalgic bliss is ultimately cut short by the boy starting to adapt the well-known tune of "If You're Happy and You Know It" to made-up racist lyrics: "If you're a Paki and unhappy, fuck off home" (p. 25). Instead of registering the boy's attack as hate speech, Rahul drily observes, "No one says anything. You don't do you, on a bus?" Rahul counters the racist affront, which denies his claims to being at home in London, by clinging onto his sense of Britishness, according to which speaking out on a bus is incompatible with national clichés of politeness and a stiff upper lip. Yet Rahul is mistaken in assuming that he can join in the "uneasy silence" that sociologist Les Back has identified as a characteristic of post-7/7 travel in London: "commuters travelled silently to work, trying not to notice the police men with their machine guns or the ethnically profiled stop-and-search policy that targeted people for being 'Asian' 
or 'Arab' looking" (Back 2007, p. 118). As Rahul is the one being targeted, he cannot help but notice how the intensified security regime starts to curtail his mobility in his own hometown.

In a later scene, set in September 2005, when the experience of being singled out on public transport has become routine for Rahul, he seems to realize that silence is no longer a convenient option for him. The humorous overtones of the encounter on the bus give way to a more sinister mood in an account strongly resembling Mohammed's speech in Sen Gupta's play:

The old lady on this train is looking at me, staring at me, she's been doing it since New Eltham, I can feel her eyes on the sweat of my neck. I turn to catch her out, and she flicks her head back to her book, like she's subtle, but she ain't.

I wish she just punch me, $\mathrm{y}^{\prime}$ know? The punch I can take, but the look ... all these frightened half-glances they ... they just...

I put on my most refined accent, and ask out loud:

'Excuse me, is this the train to Charing Cross?'

Blank faces. [ ... ] The old lady cocks her head as if to say, 'You're not fooling me!' (p. 30)

Like Mohammed, Rahul is permanently read as a potential suicide bomber whenever he travels on public transport. Heeding the innumerable public service warnings to detect suspicious behavior or items of luggage, the older woman traveling with Rahul refuses to take her eyes off him. Notably, he not only sees but feels her gaze. This indicates that the post-7/7 regime of racial profiling and policing works not only on an optical but also on a tactile, affective level. Whereas his fellow white travelers remain indistinguishable, an amorphous mass of "Blank faces", Rahul feels constantly spotted and singled out. His account elucidates what Sara Ahmed has called the "spatial politics of fear", i.e., "the way fear restricts the mobility of some and extends the mobility of others" (Ahmed 2014, p. 15). Just as Ahmed suggests that, after $9 / 11$, national subjects were invited to "stick together" in a community of fear and disgust, the white Britons that Rahul meets on public transport cohere through constructing him as a fear-inspiring object, an object that "sticks out". Rahul cannot resist the mechanism whereby he comes under suspicion merely for inhabiting a body that is invariably "associated with terrorism: Islam, Arab, Asian, East, and so on. Fear sticks to these bodies" (Ahmed 2014, p. 79; original emphasis). There seem to be no strategies available to Rahul to "unstick" the label of the could-be terrorist. Although he tries to disidentify with the fear-inducing figure by displaying his polished British English accent, his fellow travelers persist in treating him as suspect.

Even though Rahul refutes the old woman's pretense to being "subtle", he still draws a line between the veiled forms of racial discrimination he is confronted with (which he never names as such) and the violent experiences his mother has relayed to him. For instance, when she reports that "the windows at the shop have been spray painted with something obscene", he insists, "Spray paint's not exactly a brick, Mum, and people get attacked all the time, it doesn't necessarily- [ ... ]" (p. 27). Preferring to break off his sentence instead of looking for words to name hate crimes for what they are, Rahul even suggests that his mother "might be happier in India, [ . . ] back in Gujarat" (p. 27). Not only does he refuse to call out racism, but Rahul even replicates the racist logic according to which unhappy immigrants should return to their supposed home, translating the racist slur "fuck off home" from the boy's song on the bus into a slightly more polite register. As the play progresses, it becomes clear that Rahul's lack of resources to identify and resist racism prevents him from finding a legitimate outlet for the anger he builds up while living under constant suspicion. After undergoing another "random" search (under the Prevention of Terrorism Act) as he arrives at Trafalgar Square to celebrate the successful Olympic bid, Rahul lashes out at his childhood acquaintance Mihir, a third-generation British Indian, who has taken to the square to protest against the Iraq War. Mihir tries to educate Rahul about the symbolic weight of the Henry Havelock statue: "It's an affront to our people. That it's still standing is a mockery, a glorification of imperial militarism" (p. 35). Rahul cuts off Mihir's 
lecture about Britain's postimperial melancholia and starts beating him up brutally. As he explains to the audience, "I don't know why he, his lot, wanted to fuck stuff up for the rest of us who were trying so hard to make it work, I'm tired of proving-I mean, today is a day of celebration and we just fucking needed that" (p. 37). Again, Rahul lacks the precise words to explain what it is that he has been struggling to prove and to whom. The fact that he still tries to rally behind the bland patriotism displayed in view of the successful Olympic bid ("we just fucking needed that") illustrates the double bind many British Asians have found themselves in since 9/11 and the northern English riots. The community of white British citizens expects him to prove how British he feels-without, however, inviting him into the fold of anxious fellow feeling-whereas Mihir and his mother demand that Rahul assume an antiracist opposition to the nation. Mihir's hint at Britain's imperial past tips Rahul over the edge because, subconsciously, he has registered one of the key ingredients of the Britishness that he desperately holds on to: namely, that national identity is predicated on a disavowal of empire (Tyler 2012, p. 80). Somewhat ironically, Rahul embodies a conservative position of national pride (more familiar from white nationalist contexts) in rejecting the "discourse of shame about British history" and instead promoting the logic that "if you are here, you must have chosen to be here" (Holohan 2006, p. 21). His subject position thus falls within the remit of what Salman Sayyid has termed the "ironic citizenship" that defines "BrAsianness" (Sayyid 2006, p. 8). However, whereas Sayyid sees that irony as resulting from BrAsians' "recurring doubts about their inclusion within the conversation of the nation" as well as "persistent and deep-seated skepticism about the dominant mythology of Britishness" (Sayyid 2006, p. 8), the irony in Patel's play emerges precisely from Rahul's stubborn persistence in being included in a national community that seeks to exclude him.

By illustrating Rahul's conflict between divergent loyalties and identifications, True Brits evinces the extent to which subject positions situated on the domestic "home front" of the war on terror have become polarized. Rahul's childhood acquaintance joins the anti-imperial resistance, his girlfriend Jess marches against the war, his mother gives up any hope of belonging to the national community, and his schoolmate Rhys chooses the patriotic route of signing up with the British Army. Rahul's indecision and his opportunism (he only joins the antiwar march after he becomes interested in Jess, yet he still downplays Britain's imperial past and racist present) are revealed as an untenable position in the belligerent post-7/7 social climate. Yet the play, by and large, sanctions none of the characters' views on what might make a citizen the eponymous "true Brit". Rahul's stubborn insistence that he is entitled to feel at home in London despite coming under constant suspicion is not rejected as wholly naïve or ignorant. In the reconciliatory final part of the monologue, which harks back to the 2012 Olympics, Rahul and his mother have found something of a middle ground where they stake a claim to national belonging without relinquishing their (in Rahul's case, newly developed) skepticism. While his mother buys tickets for the closing ceremony concert by quintessential Britpop band Blur, Rahul allows himself a final, slightly more sober moment of "minor rapture", as the stage directions stipulate: "I saw the Olympic Games in my city, in my country, in my lifetime!" (p. 43). He might still be lacking the words to pinpoint social problems such as racism, but he does acknowledge that, despite the massive "Olympian effort", "there's still a way to go" for the UK (p. 44).

\section{3. "Home Is a Currency": Spotting Opportunities in Abhishek Majumdar's Harlesden High Street (2010/2013)}

Abhishek Majumdar's play Harlesden High Street resembles True Brits in its exploration of persistent attachments to the nation-home in spite of the climate of suspicion. Bangalore-based playwright Majumdar completed a residency at the Royal Court Theatre in London in 2011 and intensified his collaborations with UK theater institutions in the following years. After a first performance at Jnana Jyothi Auditorium in Bangalore in 2010, Harlesden High Street received its London premiere in cooperation with British Asian theater company Tara Arts in 2013. The three-hander, written in the form of unrhymed free verse, focuses on Rehaan (who has recently arrived from Karachi), Karim (a second-generation British Pakistani), and his mother, Ammi. Throughout the play, the characters 
ponder the question of what home means for them in duologues and extended soliloquies. In contrast to Sen Gupta and Patel, Majumdar chose a character representative of the first generation to offer an extensive commentary on the changed status of British Asians after the 7/7 attacks. Despite the fact that both Rehaan and Karim (like the young male characters discussed above) are likely to fall under suspicion in the new racialized security regimes, Ammi is the one who is more acutely aware of how counterterrorist measures affect her and her family's mobility. Ammi emphasizes at various points that her eyesight is failing her as she awaits an essential surgical operation. By choosing an older female character with impaired vision to speak about the war on terror, Majumdar submits the climate of suspicion to scrutiny and provides an ironic comment on the excessive emphasis on optical surveillance.

Ammi's soliloquy begins with a joke about how the "mayor had hiked up property prices in Zone 2, so that few people could be around Firoza", her "extremely beautiful" daughter (Majumdar 2013, p. 441). ${ }^{4}$ Within the space of this brief joke, Ammi at once demonstrates her local expertise and inside knowledge: she refers to London travel zones (rather than boroughs) and jokingly joins the chorus of Londoners who routinely protest rising property prices. Ammi does not connect her family's dwelling in London to conceptions of ethnic neighborhoods that predominate the discourse about British Asian segregation after 2001. Instead, she casually remarks that they "used to stay around Acton" (p. 441) until changing conditions in the housing market made that area as unaffordable for them as for many other Londoners. Similarly, when she begins speaking about the public transport network, she not only immediately displays her thorough knowledge of routes but also ties that network to her own family tree. Taking up the line "Home is ... " from a previous scene involving Rehaan and Karim, she tells the story of how she met the father of her children when he was working as a bus driver:

Home ... home is where Anwar Saheb is.

[... ] [W]e got married. In a bus! And we travelled ... every day the same route. I kept sitting in the first seat all day, with his lunch box.

And we made love, in bus stations. Ealing. Acton. [ ... ]

Hammersmith, that's where I conceived Firoza. Last seat of bus 260. Upstairs. (p. 452)

It is important that Ammi's speech establishes her intimate (in all senses of the word) knowledge of the transport network in London before she first mentions the 2005 terror attacks. The iconic double-decker bus, for her, is an intensely familiar everyday environment where she has experienced courtship, sex, and daily commutes. Hence, audiences might surmise that the sight of the burnt-out bus in Tavistock Square will have horrified her. Yet she neither positions herself as a victim (i.e., on the side of those attacked or affected) nor endorses the dominant rhetoric "chorused by Tony Blair, that it is 'bad Muslims' who are responsible for terrorism, while 'good Muslims', on the other hand, [... ] are innately decent, God-fearing folk" (Bharucha 2014, p. 93). Instead, Ammi contextualizes the attack with a view to the longer history of bombings that Londoners of her age group will have witnessed. Going back to her alleged conception of her daughter on a 260 bus, she recounts,

In those days, every time there was a bomb scare, they rounded up the Irish. It used to be difficult. It's difficult to tell, till one hears them speak. Bus halts were long. [ ... ]

Nowadays bomb scares are more frequent. But bus halts are shorter.

You see, it's easier to tell. They couldn't tell the Irish from the others ... but with Asians, it's far easier. [... ] 
Actually they can't tell Pakistanis from Indians or Arabs in general. But I don't think that matters. They don't see too well either. (p. 478)

It is notable that Ammi neither uses the familiar temporal marker " $7 / 7$ " nor refers explicitly to the London bombings. By foregrounding the continuities of terrorism and counterterrorism in the postcolonial metropolis, Ammi refutes the dominant tendency to situate the more recent Islamist attacks in an ahistorical vacuum. Her dry tone and wry observations underline the "grim truth", as sociologist Back has put it, "that there is nothing exceptional about bombings in London" (Back 2007, p. 132). She also establishes an explicit analogy between the creation of an Irish suspect community from the 1970s onwards and the "suspectification" (Hickman et al. 2011, p. 10) of British Muslims since 2001. Using apparently simple, colloquial English, Ammi's line "You see, it's easier to tell" offers a complex, ironic commentary on the mechanics of racial profiling. The supposedly "easier" identification of suspects by means of visual parameters (in the case of "Asians"), as opposed to acoustic parameters (in the case of "the Irish"), hinges on ocular tools that are inherently flawed ("They don't see too well either"). Ammi's observation throws into sharp relief the defects of the "regime of racialised visuality" that has operated "[w]ithin the civic spaces of the London metropolis" after the 2005 bombings to mark its "transient subjects as either obviously 'foreign' or self-evidently 'native'" (Pugliese 2006).

In contrast to the despair and anger to which the younger male characters in Sen Gupta's and Patel's plays are driven as a result of constantly falling under suspicion, Ammi distills a constructive insight from the Pakistani community being repositioned as suspect: "Eyes ... one must take care of one's eyes in the world. [ . . . ] It's all about spotting. Spotting opportunities, spotting danger" (p. 490). Instead of seeing herself or her community more widely as victims of racial profiling and discrimination, Ammi aligns their situation with that of the British security apparatus. Just as intelligence and police officers (and the alarmed white citizens acting as their extended wing) are surveying public spaces and the transport system to "spot danger", those who are "living on someone else's land" (p. 490) must train their visual capabilities to spot "opportunities". Ammi and her family are tasked with finding places and transport routes that they can still inhabit and traverse under the current circumstances. However, the idea of "spotting opportunities" also, and perhaps more obviously, has an economic dimension, tying Ammi's monologue to the scenes involving Karim and Rehaan. Ammi's son and his colleague and friend Rehaan are, for most of the play, engaged with the question of how to attract customers to their small grocery store. Unlike Ammi, they neither discuss the London bombings nor their own implication in the culture of suspicion. Yet their duologues pick up on Ammi's gesture towards the interchangeability of suspect communities by emphasizing the instability of national descriptors. In line with their role as shopkeepers, Rehaan and Karim foreground the economic nature of migration, transposed onto types of fruit:

Rehaan. These fruits, I feel sorry for them. They aren't meant for this weather.

Karim. But they want it ... they demand, we supply.

Rehaan. Wrong fruits.

Karim. Right fruits. Wrong place.

Rehaan. Hybrids. (pp. 318-33)

Just as fruits come into and go out of season, the men imply, the success of migrants' arrival in the UK depends on "Timing" (p. 333). Their desirability to the national economy is regulated by supply and demand. By thus depending on the rules of the market, their belonging to the nation can only ever be conditional and contingent. The seemingly straightforward labeling of racialized bodies that are seen as being "foreign" to the nation, and thus as potentially dangerous, does not stand up to scrutiny in a globalized, interconnected Britain: most fruits are "Hybrids" rather than indigenous to a certain time and place. 
Karim and Rehaan also adapt their conceptions of home to the fluidity that they ascribe to national identities. When Rehaan uses a phrase considered typical of first-generation immigrants, remarking that surgery would be "cheaper back home" (p. 403), Karim laughs about the phrase, and they begin trading different definitions of home:

Rehaan. Home ... home is where it's cheaper.

Karim. Home is where one earns more.

Rehaan. Home is where one saves more. [ . . ] Home is where one can send more home.

Karim. Home is a currency. A currency that's eighty - ninety times one's own. It's a calling card, a money transfer. (p. 419)

At the end of the exchange, it is no longer clear whether "home" is London or Karachi. Either place is an interchangeable location that orients the subject towards the other place in an economic transaction, such as sending money from one home (London) to the other (Karachi). The conclusion that "Home is a currency" locates home in transit, in the medium of exchange that permits establishing a relationship between two places. "Home" is thus fundamentally a question of the market, of exchange rates and circulation; where one feels "at home" will inevitably shift. In trading versions of home that stress economic opportunity rather than hardship, Karim and Rehaan appear to endorse a lighthearted view of postmodern fluidity and postcolonial relations. Echoing the influential observation made in Paul Gilroy's The Black Atlantic in 1993 (Ali et al. 2006, p. 326), the men situate (their) national belonging in terms of routes rather than roots. In view of the global flows of capital, goods, and people (the fruits symbolizing all three), locating oneself at a vantage point in the "new" homeland where one looks "back home" - implying both a temporal and spatial unidirectionality—no longer makes sense. By affirming the mutability of home and belonging, Harlesden High Street reevaluates the contingencies of British South Asian citizenship after 7/7 in terms of personal and economic flexibility. As reviewers remarked (Loxton 2013), Tara Arts' stage production accentuated this emphasis on fluidity, as the actors constantly rearranged wooden crates that symbolized both their merchandise and the "tower blocks" characteristic of London or Karachi. Facing the same social problems of suspicion and stigmatization explored in other South Asian theater productions after 7/7, the characters in Harlesden High Street nevertheless continuously reinvent and rebuild their homes in North West London. In contrast to Mohammed or Rahul, who cannot disengage from external categorizations as terrorist suspects, Majumdar's characters retain some agency over defining their belonging to the nation-home. In the penultimate scene, the bodies of the young Asian men even become protective (rather than threatening) elements in public space as Rehaan and Karim pull out a plastic cover in front of their shop to offer passersby shelter from the rain. The play thus subtly recodes hostility in terms of hospitability.

\section{Conclusions}

Commenting on the impact of racial profiling and securitization on multicultural conviviality in London, Les Back has insightfully elucidated how the "politics of misrecognition and fear damages the choreography of life. It undermines [... ] our ability to coexist and share the public space of the bus or underground carriage" (Back 2007, p. 145). British South Asian theater productions since 7/7 have invited audiences to consider their own investment in the politics of misrecognition and suspicion. Traveling to London theater venues on public transport, they will have been exposed to service announcements and counterterrorist publicity posters advising them to track and report suspicious passengers. Productions such as What Fatima Did ... , True Brits, or Harlesden High Street pick up on these visual cues from counterterrorism campaigns. At the same time, these plays variously confound and problematize the ways in which white citizens are trained to perceive presumably suspect racialized bodies. By giving a voice, a body, and an innocuous personification to the figure of the traveling terrorist suspect-through crafting ambivalent, confused, largely likeable young male 
characters-these British South Asian theater productions encourage empathetic relations that reach beyond the Manichean binaries of the war on terror. With their final, reconciliatory scenes, both True Brits and Harlesden High Street venture to stage moments of harmonious coexistence. Mobilizing the resources of stubborn persistence (Patel) or entrepreneurial wit (Majumdar) against the erosion of citizenship rights and national belonging, both plays invent strategies for building, making, or keeping a home in London in spite of the strictures of suspectification and securitization.

As this article has shown, British South Asian theater productions merit particular scholarly attention for their negotiation of questions of national belonging in the war on terror period. The corpus of plays identified here emphasizes the social problems affecting the second and third generation of South Asians, who have unwaveringly identified Britain as their home until the onset of the post-9/11 political world. For these characters, home is no longer congruent with their families' places of origin, with which they might have little familiarity or attachment. Yet the resignification of home in terms of "routes" rather than "roots" (as is presumably characteristic of diasporic postcolonial subjects) is equally fraught; after all, the protagonists' navigation of urban routes and public infrastructure is crucially restricted by the new security regimes. The postcolonial subjects dramatized in British South Asian theater after 7/7 persist, stubbornly or creatively, in maintaining their claims to the UK as the nation-home. In so doing, characters such as Rahul, Ammi, Rehaan, and Karim challenge spectators to acknowledge their bonds to the nation as valid and stable rather than demanding constant renewal and proof.

Funding: This research received no external funding.

Conflicts of Interest: The author declares no conflict of interest.

\section{References}

Ahmed, Sara. 2014. The Cultural Politics of Emotion. Edinburgh: Edinburgh University Press. First published 2004. Ali, Nasreen, Virinder S. Kalra, and Salman Sayyid. 2006. Part III: Signatures. In A Postcolonial People: South Asians in Britain. Edited by Nasreen Ali, Virinder S. Kalra and Salman Sayyid. London: C. Hurst, pp. 315-26.

Back, Les. 2007. The Art of Listening. Oxford: Berg.

Bharucha, Rustom. 2014. Terror and Performance. London: Routledge.

Boll, Julia. 2013. The New War Plays: From Kane to Harris. Basingstoke: Palgrave Macmillan.

Daboo, Jerri. 2018. Staging British South Asian Culture: Bollywood and Bhangra in British Theatre. Abingdon: Routledge. Dadswell, Sarah. 2009. What Is This Thing Called British Asian Theatre? Contemporary Theatre Review 19: 221-26. [CrossRef]

de Waal, Ariane. 2017. Theatre on Terror: Subject Positions in British Drama. Berlin: De Gruyter.

Finburgh, Clare. 2017. Watching War on the Twenty-First Century Stage: Spectacles of Conflict. London: Bloomsbury Methuen Drama.

Hickman, Mary J., Lyn Thomas, Sara Silvestri, and Henri Nickels. 2011. 'Suspect Communities'? Counter-terrorism Policy, the Press, and the Impact on Irish and Muslim Communities in Britain. London: London Metropolitan University.

Hingorani, Dominic. 2010. British Asian Theatre: Dramaturgy, Process and Performance. Basingstoke: Palgrave Macmillan.

Holohan, Siobhan. 2006. New Labour, Multiculturalism and the Media in Britain. In Muslims and the News Media. Edited by Elizabeth Poole and John E. Richardson. London: I.B. Tauris, pp. 13-23.

Hughes, Jenny. 2011. Performance in a Time of Terror: Critical Mimesis and the Age of Uncertainty. Manchester: Manchester University Press.

Knight, Sam. 2020. If Shamima Begum, the ISIS Bride, Is No Longer British, What Does Citizenship Mean? The New Yorker, February 15. Available online: https://www.newyorker.com/news/letter-from-the-uk/ifshamima-begum-the-isis-bride-is-no-longer-british-what-does-citizenship-mean (accessed on 1 April 2020).

Kundnani, Arun. 2007. Integrationism: The Politics of Anti-Muslim Racism. Race and Class 48: 24-44. [CrossRef]

Ley, Graham, and Sarah Dadswell, eds. 2012a. British South Asian Theatres: A Documented History. Exeter: Exeter University Press.

Ley, Graham, and Sarah Dadswell, eds. 2012b. Critical Essays on British South Asian Theatre. Exeter: Exeter University Press. 
Loxton, Howard. 2013. Harlesden High Street (Review). British Theatre Guide, n.d. Available online: https: //www.britishtheatreguide.info/reviews/harlesden-high-8918 (accessed on 27 April 2020).

Majumdar, Abhishek. 2013. Harlesden High Street. London: Oberon Books, Kindle Edition.

Modood, Tariq. 2005. Multicultural Politics: Racism, Ethnicity and Muslims in Britain. Edinburgh: Edinburgh University Press.

Patel, Vinay. 2014. True Brits. London: Bloomsbury Methuen Drama.

Pugliese, Joseph. 2006. Asymmetries of Terror: Visual Regimes of Racial Profiling and the Shooting of Jean Charles de Menezes in the Context of the War in Iraq. Borderlands E-journal 5. Available online: http: //www.borderlands.net.au/vol5no1_2006/pugliese.htm (accessed on 2 April 2020).

Samad, Yunas. 2016. Community Cohesion without Parallel Lives in Bradford. In Social Cohesion and Social Change in Europe. Edited by Gerard Boucher and Yunas Samad. Abingdon: Routledge, pp. 73-91.

Sayyid, Salman. 2006. Introduction: BrAsians; Postcolonial People, Ironic Citizens. In A Postcolonial People: South Asians in Britain. Edited by Nasreen Ali, Virinder S. Kalra and Salman Sayyid. London: C. Hurst, pp. 1-10. Sen Gupta, Atiha. 2009. What Fatima Did ... . London: Oberon Books.

Sharma, Nandita. 2006. White Nationalism, Illegality and Imperialism: Border Controls as Ideology. In (En)Gendering the War on Terror: War Stories and Camouflaged Politics. Edited by Krista Hunt and Kim Rygiel. Aldershot: Ashgate, pp. 121-43.

Soncini, Sara. 2015. Forms of Conflict: Contemporary Wars on the British Stage. Exeter: University of Exeter Press.

Summerfield, Penny, and Corinna Peniston-Bird. 2007. Contesting Home Defence: Men, Women and the Home Guard in the Second World War. Manchester: Manchester University Press.

Tyler, Katharine. 2012. Whiteness, Class and the Legacies of Empire: On Home Ground. Basingstoke: Palgrave Macmillan. van Houdt, Friso, Semin Suvarierol, and Willem Schinkel. 2011. Neoliberal Communitarian Citizenship: Current Trends towards 'Earned Citizenship' in the United Kingdom, France and the Netherlands. International Sociology 26: 408-32. [CrossRef]

(C) 2020 by the author. Licensee MDPI, Basel, Switzerland. This article is an open access article distributed under the terms and conditions of the Creative Commons Attribution (CC BY) license (http://creativecommons.org/licenses/by/4.0/). 